\title{
Comparison of Antioxidative Activities of Ubiquinol-4 and $\alpha$-Tocopherol against Methyl Linoleate Peroxidation and Their Cooperative Effect
}

\author{
Jin Ye WanG*, Teruo Miyazawa, and Kenshiro Fujimoto \\ Department of Food Chemistry, Faculty of Agriculture, Tohoku University \\ (1-1, Tsutsumidori-Amamiyamachi, Aoba-ku, Sendai-shi, T981)
}

A comparison was made of the antioxidative activity of ubiquinol-4 $\left(\mathrm{H}_{2} \mathrm{CoQ}_{4}\right)$ and $\alpha$-tocopherol $(\alpha-\mathrm{TOC})$ in methyl linoleate system by gas chromatography (GC) and measuring the oxygen consumption of the head space gas. The synergistic effect of $\mathrm{H}_{2} \mathrm{CoQ}_{4}$ on $\alpha$-TOC was also studied. At various concentrations, the activity of $\mathrm{H}_{2} \mathrm{CoQ}_{4}$ was weaker than that of $\alpha$-TOC $; 0.7 \% \mathrm{H}_{2} \mathrm{CoQ}_{4}$ addition showed the same effect as $0.33 \% \alpha$-TOC addition. When present together, the efficiency was about the sum of their individual efficiencies, and synergistic effect of $\mathrm{H}_{2} \mathrm{CoQ}_{4}$ toward $\alpha$-TOC could not be detected.

\section{Introduction}

As a kind of lipid -soluble compounds existed in biomembranes, ubiquinone and its reduced form ubiquinol have been considered to be important antioxidants beyond $\alpha-\mathrm{TOC}^{1)-3)}$. It seems to be more significant because ubiquinones are present at higher concentrations than $\alpha-$ TOC and are constantly being regenerated by the electron transfer system in mitochondria ${ }^{1)}$. Recently, Packer's group has reported that although tocopherols are much stronger membrane antioxidants than naturally occurring ubiquinols (ubiquinones), the later can synergistically enhance enzymic NADH- and NADPH-dependent recycling of tocopherols by electron transport in mitochondria and microsomes ${ }^{4), 5}$. These reports are limited to the model membranes, little is known about the effect of ubiquinone (ubiquinol) on the autoxidation of edible oil in bulk phase compared with $\alpha$-TOC. In the present paper, we investigated the antioxidant efficiencies of $\alpha$ TOC and $\mathrm{H}_{2} \mathrm{CoQ}_{4}$ and their synergistic effect against methyl linoleate peroxidation to discuss the possible application of ubiquinone -4 as an oral administration antioxidant. We choose ubiquinone -4 because its structure is similar to $\alpha$ TOC in phenyl chain and it is said to be more effective than ubiquinone-10 against the vitamin E defficiency, although ubiquinone-9 and ubi-
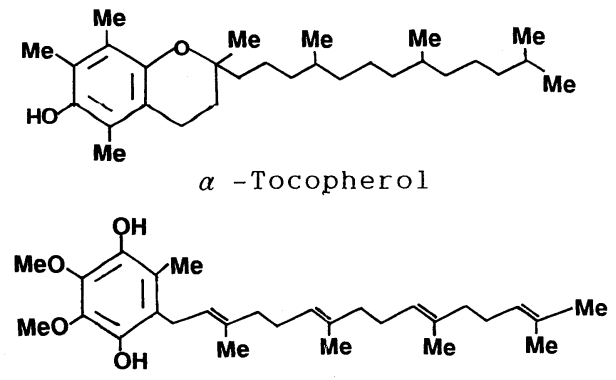

Ubiquinol-4

Scheme-1

quinone-10 are the major ubiquinone analogues existed in biomembranes of animals and they can be biosynthesized by themselves ${ }^{6) \sim 8)}$. These observations imply its spare or substitutive effect for $\alpha$-TOC. Moreover, the morecular weight of $\mathrm{H}_{2} \mathrm{CoQ}_{4}$ is about the same of $\alpha$-TOC, which is favorable to compare their antioxidative activities in weight addition level (Scheme-1).

\section{Experimental}

\subsection{Material}

$d l-\alpha-$ TOC $(99.8 \%)$ and ubiquinone-4 were generous gifts of Eisai Co. Ltd., Tokyo. Methyl linoleate $(>99 \%$ pure $)$ was prepared according to reference 9 . Reduced $\mathrm{Co}_{4}$ solution was prepared immediately prior to use by reduction in ethanol with $\mathrm{NaBH}_{4}$, followed by extraction with hexane 
(separated into two layers by degassed distilled water). The solution was kept under $\mathrm{N}_{2}$ atomosphere and protected from light.

\section{$2 \cdot 2$ Methods}

For one test, $1 \mathrm{~g}$ of methyl linoleate containing $\alpha$-TOC and/or $\mathrm{H}_{2} \mathrm{CoQ}_{4}$ was put into a $15-\mathrm{mL}$ glass test tube and sealed it with a $\mathrm{W}$-type rubber cap, then stored at $60^{\circ} \mathrm{C}$ in the dark. Absorbed oxygen level in the head space of the test tube was measured by gas chromatography with a thermoconductivity detector ${ }^{9)}$.

\section{Results}

\section{$3 \cdot 1$ Comparison of antioxidative activities of $\alpha$-TOC and $\mathrm{H}_{2} \mathrm{CoQ}_{4}$}

The amounts of oxygen absorption in test tubes are shown in Fig. - 1. It is considered to reach a plateau when oxygen absorption was over $2.0 \mathrm{~mL}^{10)}$, the days were used to compare the antioxidant activity. Methyl linoleate containing $0.18 \% \alpha-$ TOC was oxidized within $6 \mathrm{~d}$ compared with $2 \mathrm{~d}$ of $\alpha$-TOC free substrate oil. About double amount of supplementation $(0.33 \%)$ didn't enhance the activity, and about six-times amount of supplementation prolonged the period only to $8 \mathrm{~d}$ (Fig. -1 a). These results indicate that an optimum concentration of $\alpha$-TOC exists to obtain an effective antioxidative activity against methyl linoleate peroxidation. On the other hand, $\mathrm{H}_{2} \mathrm{CoQ}_{4}$ gave a weaker activity as comparison with $\alpha$-TOC. $0.3 \%$ of $\mathrm{H}_{2} \mathrm{CoQ}_{4}$ addition

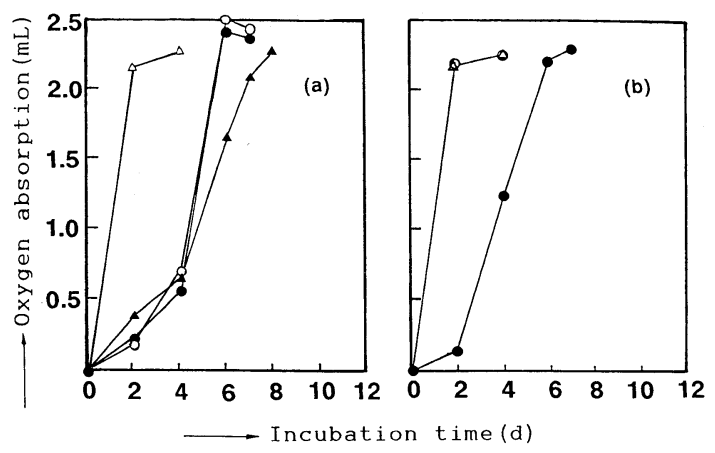

(a) $\alpha$-TOC addition, methyl linoleate only $(\triangle) ; 0.18 \%$ of $\alpha$-TOC $(\bigcirc) ; 0.33 \%$ of $\alpha$ $\operatorname{TOC}(\bigcirc) ; 1.1 \%$ of $\alpha-\operatorname{TOC}(\boldsymbol{\Delta})$. (b) $\mathrm{H}_{2} \mathrm{CoQ}_{4}$ addition, methyl linoleate only $(\triangle) ; 0.3 \%$ of $\mathrm{H}_{2} \mathrm{CoQ}_{4}(\bigcirc) ; 0.7 \%$ of $\mathrm{H}_{2} \mathrm{CoQ}_{4}(\bigcirc)$.

Fig.-1 Antioxidant activities of $\alpha$-TOC and $\mathrm{H}_{2} \mathrm{CoQ}_{4}$ against methyl linoleate autoxidation during storage at $60^{\circ} \mathrm{C}$.
Table-1 Cooperative effect of $\alpha$-tocopherol and ubiquinol-4 against methyl linoleate peroxidation. Each value indicates the number of days requierd to reach a plateau on oxygen uptake curve.

\begin{tabular}{l|l|l|l|l}
\hline \multirow{2}{*}{ Compound added } & \multicolumn{3}{c}{$\alpha$--Tocopherol } \\
\cline { 3 - 5 } \multicolumn{2}{c|}{} & 0 & $0.18 \%$ & $0.33 \%$ \\
\hline \multirow{3}{*}{ Ubiquinol-4 } & 0 & 2 & 6 & 6 \\
& $0.3 \%$ & 2 & 8 & 8 \\
& $0.7 \%$ & 6 & 12 & 12 \\
\hline
\end{tabular}

didn't inhibit the peroxidation of methyl linoleate. Above twice as amount of addition $(0.7 \%)$ reached the same efficacy of $0.18 \%$ or $0.33 \%$ of $\alpha$-TOC addition (Fig. -1 b).

\section{$3 \cdot 2$ Investigation of cooperative effect of} $\mathrm{H}_{2} \mathrm{CoQ}_{4}$ to $\alpha$-TOC

When $\alpha$-TOC was coexisted with $\mathrm{H}_{2} \mathrm{CoQ}_{4}$, the efficacy was about the sum of individual efficacy of them. To understand it easily, we showed the result in Table-1. For example, $0.33 \%$ of $\alpha$ TOC increased the storage period to $6 \mathrm{~d}$, while $0.7 \%$ of $\mathrm{H}_{2} \mathrm{CoQ}_{4}$ also increased it to $6 \mathrm{~d}$. Coexistence of $0.33 \%$ of $\alpha$-TOC and $0.7 \%$ of $\mathrm{H}_{2} \mathrm{CoQ}_{4}$ increased the period to $12 \mathrm{~d}$. No synergistic effect was observed.

\section{Discussion}

Under our experimental conditions (incubation at $60^{\circ} \mathrm{C}$ under air), a substantial portion of $\mathrm{H}_{2} \mathrm{CoQ}_{4}$ might be consumed by autoxidation of itself and could not play the role of an antioxidant ${ }^{11)}$, i.e., the real amount of antioxidative $\mathrm{H}_{2} \mathrm{CoQ}_{4}$ was lower than that expressed in Fig. -1 and Table-1. Its weaker antioxidative efficacy than $\alpha$-TOC may be derived from the above reason. The mechanism by which $\mathrm{H}_{2} \mathrm{CoQ}_{4}$ and other reduced coenzyme $Q$ act as antioxidants remains unsolved thoroughly, Frei et al. have suggested that they trap free radicals and inhibit the propagation reaction of lipid peroxidation at least by their hydrogen-donating abilities similar to $\alpha$-TOC, although they cannot be recycled by ascorbate, most importantly, they can be recycled by the mitochondrial respiratory chain ${ }^{11}$. Another possible mechanism is suggested that they can react with $\mathrm{ADP}$-perferryl ions or with superoxide directly and thus interfere with the initiation of lipid peroxidation ${ }^{12)}$. 
Kagan et al. have reported that the antioxidant effects of ubiquinones in microsomes and mitochondria are mediated by tocopherol recycling, which is NADH- and NADPH-dependent $t^{4}$. In our systems used, absence of the regeneration of $\alpha$-TOC by ubiquinone may be due to the absence of NADH- and NADPH-dependent recycling system. During our paper was reviewed, we read Yamamoto et al. 's report which suggests that ubiquinol-10 can regenerate $\alpha$-TOC by reducing $\alpha$-tocopheroxyl radical ${ }^{13)}$, but they did not show direct evidence. It shouldn't ignore that ubiquinol is more easily autoxidized than $\alpha$ TOC. Administration of ubiquinone inhibited ethanol- and carbon tetrachloride-stimulated lipid peroxidation of rats ${ }^{14)}$, and in elderly animals ubiquinone levels dropped drastically in heart, kidney, and highly aerobic (red) muscles $^{15)}$. On the basis of results in vivo and in bulk phase, ubiquinone shows a possible application in oral administration as an antioxidant which can spare and substitute for $\alpha$-TOC.

(Received Feb. 28, 1991)

\section{References}

1) A. Mellors. and A. L. Tappel, J. Biol. Chem., 241, 4353 (1966).

2) N. R. Di Luzio, Fed. Proceed., 32, 1875 (1973).

3) L. Landi, D. Fiorentini, L. Cabrini, C. Stefanelli, and A.M. Sechi, Biochim. Biophys. Acta, 984, 21 (1989).

4) J. J. Maguire, D. S. Wilson, and L. Packer, J. Biol. Chem., 264, 21462 (1989).

5) V. Kagan, E. Serbinova, and L. Packer, Biochem. Biophys. Res. Commun., 169, 851 (1990).

6) T. M. Farley, G.D. Jr. Daves, and J. Scholler,
Intern. Z. Vit. Forsh., 38, 355 (1968).

7) C.D. Fitch, J.S. Dinning, and F.S. Porter, Arch. Biochem. Biophys., 112, 488 (1965).

8) C. D. Fitch, and F.S. Porter, J. Nutr., 89, 251 (1966).

9) J.Y. Wang, K. Fujimoto, T. Miyazawa, and Y. Endo, J. Agric. Food Chem., 39, 351 (1991).

10) J. Y. Wang, T. Miyazawa, and K. Fujimoto, Agric. Biol. Chem., 55, 1531 (1991).

11) B. Frei, M.C. Kim, and B. N. Ames, Proc. Natl. Acad. Sci. USA, 87, 4879 (1990).

12 ) B. A. Svingen, J. A. Buege, F. O. O'Neal, and S. D. Aust, J. Biol. Chem., 254, 5892 (1979).

13) Y. Yamamoto, E. Komuro, and E. Niki, J. Nutr. Sci. Vitaminal., 36, 505 (1990).

14) E. B. Robert, Free Rad. Biol. Med., 5, 297 (1988).

15) R. E. Beyer, B. -A. Burnett, K. J. Cartwright, D. W. Edington, J. J. Falzon, K. R. Kreitman, T.W. Kuhn, B. J. Ramp, S. Y.S. Rhee, J. J. Rosenwasser, M. Stein, and L. C.-I, An, Mech. Ageing Dev., 32, 267 (1985).

リノール酸メチル自動酸化に対する $\alpha-ト コ$ フェロールとユビキノール-4の酸化防止力 の比較及び共存効果

\section{王＼cjkstart瑾瞱・宮澤陽夫・藤本健四郎 東北大学農学部食糧化学科 ( 9981 仙台市青葉区堤通雨宮町)}

リノール酸メチルに対する $\alpha$-トコフェロール，ユビ キノール-4の酸化防止力は $\mathrm{GC}$ 法の酸素吸収量によっ

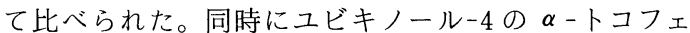
ロールへの相乗作用も調べられた。ユビキノールー4の

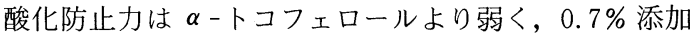
量のユビキノール -4 の酸化防止力は $0.33 \%$ 添加量の $\alpha$ -トコフェロールのそれに相当した。また，共存した場 合の酸化防止強度はそれぞれの和であった。つまり，工 ビキノール-4の相乗作用は認められなかった。 